\title{
DYNAMIC CAPABILITIES IN THE PROCESS OF BUILDING THE EFFECTIVENESS OF THE BUSINESS MODEL OF RETAIL FUEL SALES MARKET
}

\author{
Katarzyna Rajewska \\ Poznań University of Economics and Business, Poznań, Poland \\ e-mail: katarzyna.rajewska@phd.ue.poznan.pl \\ ORCID: 0000-0001-9159-3101 \\ (C) 2019 Katarzyna Rajewska \\ This is an open access article distributed under the Creative Commons Attribution-NonCommercial-NoDerivs license \\ (http://creativecommons.org/licenses/by-nc-nd/3.0/) \\ DOI: $10.15611 / \mathrm{ms} .2019 .3 .03$ \\ JEL Classification: L2
}

\begin{abstract}
The aim of the article is to promote research on the concept of dynamic capabilities in the process of building the efficiency of the business model of enterprises on the fuel sales market. The starting point of the article is the presentation of the retail fuel sales market in Poland and possible change scenarios. The dynamic development of the sector has made fuel stations an important element of public infrastructure. However, due to the high level of competitiveness, the entities manage differently with survival and their development. The concept of dynamic capabilities, which is one of the most promising approaches to explaining differences in financial results, seems to be interesting. The article shows some of the results of the research procedure conducted among participants of the fuel sales market in relation to the environment of the organization, business model and dynamic capabilities in terms of both process and resources.
\end{abstract}

Keywords: retail fuel sales market, dynamic capabilities, effectiveness, business models.

\section{Introduction}

The aim of the article is to promote research on dynamic capability as a concept of strategic management. The presented part of the research is an attempt to identify and analyze the dynamic capabilities in the process of building the effectiveness of enterprises on the retail fuel sales market in Poland. Research findings are a part of a wider project which sets out to offer a paradigm for the concept of dynamic capabilities as it applies to strategic management.

The high level of competitiveness on the retail market of fuel sales means that despite the similar offer and similar external conditions of operation, entities deal with the problem of existence and development differently, obtaining different results. The transformation processes of the nineties and the expansion of Western corporations changed the shape of the fuel market, modifying the nature of the fuel station, by introducing new forms of retail and convenience stores.

The dynamic development of the sector has made fuel stations an important element of public infrastructure, at the same time being a catalyst for the economic growth and a generator for creating new jobs. Because Poland is one of the fastest growing European markets, western concerns are constantly looking for opportunities to increase their shares, which changes the structure of the market. It should be emphasized, however, that domestic companies play an important role too.

At the same time, it can be observed that some entities focus on sustainable organic growth and development, others on extensive development, expanding the business at the pace that both the market and the organizational and financial capabilities of 
the entrants allow. For investors, Poland has been one of the fastest growing economies in Europe. We can observe an increase in purchasing power, investment in infrastructure (road network), which is a very important element of pre-emptive analysis. In this market situation, the ability to build competitive advantage becomes a key competence.

\section{The retail fuel sales market in Poland}

Nonetheless, the Polish market of retail fuel sales is heterogeneous. There are both companies with the state treasury and foreign corporations as well as independent operators. On the retail fuel sales market one can distinguish: premium fuel station segment with a full offer and 24/7 stores, an economy segment, unmanned stations, stations located next to supermarkets and highway stations.



Figure 1. Structure of the fuel market in Poland

Source: Annual report 2018 POPIHN (Polish Oil Industry and Trade Organization).

Currently, 7765 stations operate in Poland, and thanks to the fact that stations have been included in official statistics, the number of independent stations has only seemingly increased, some of them functioned earlier, but were not visible for the statistics implemented by POPIHN. Thanks to the URE (Energy Regulatory Office) database, it is possible to determine for the first time how many independent stations are operating in Poland.

The effect of scale becomes extremely important because market share determines the strength of the entity on the market and its impact on other participants. On the retail market of fuel sales, a high level of competitiveness can be observed. Thus, the advantage achieved is temporary, and new products and solutions are quickly copied.

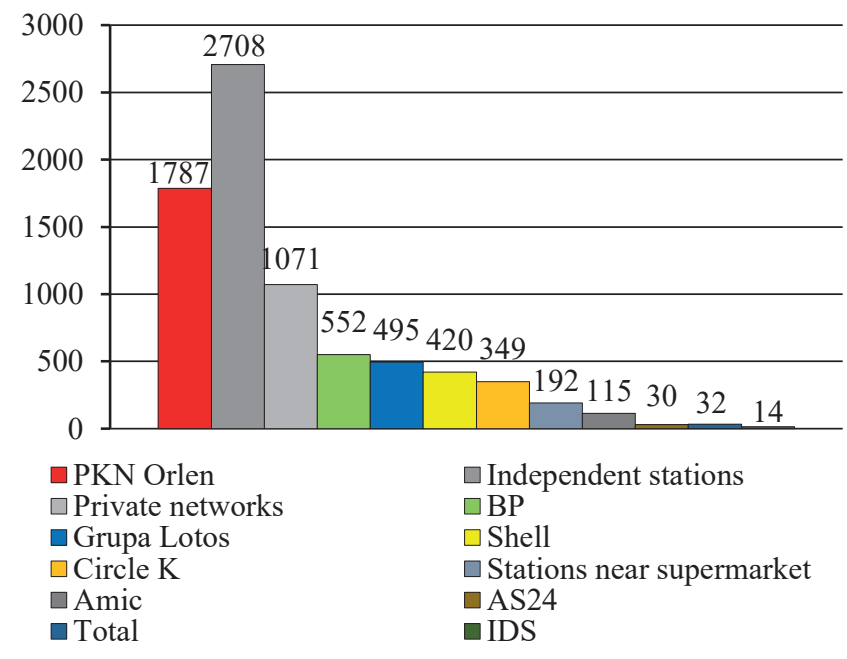

Figure 2. Number of stations on retail fuel market

Source: Annual report 2018 POPIHN (Polish Oil Industry and Trade Organization).

The dynamic development of the automotive industry, the offer of electric and hybrid cars, as well as taking steps to reduce $\mathrm{CO} 2$ will result in significant changes. The likely drop in sales of fuel engine cars will lead to a reduction in the number of petrol stations, which will change the rules of the game in the industry, but the question arises if the time when it may happen can be easily predicted.

Poland has an older car fleet, generally supplied as used vehicles from Western Europe, which is why it is difficult to expect the end or reduction of fuel consumption in the near future in comparison to Western Europe. The popularity of electric vehicles is still low due to the relatively high prices of electric vehicles and to the scarce infrastructure, and therefore limited incentives to find the owners of electric vehicles.

On the other hand, the document regulating the development and functioning of alternative fuels infrastructure as a whole is the Act on Electromobility and Alternative Fuels, which entered into force in February 2018. This act sets out the path of development and construction of nationwide vehicle charging stations and natural gas refueling stations.

It seems that both the location of petrol stations and existing infrastructure support the use of the space for the charging of electric vehicles. National concerns have already begun investing in infrastructure for charging vehicles with electricity. According to the plan by the end of 2020, 6k of charging points with normal power and 400 high-power points will be installed. On the other hand, POPIHN prepared estimates of fuel demands by 2030 , based on historical data, sales for 2018, trends and results from previous years and large increases which are still being assessed [Annual Report 2018]. 


\section{The concept of dynamic capabilities and business model adopted in research}

Searching for the answer to the question about optimal functioning means that organizations are interested in the concept of dynamic capabilities, which is one of the most promising approaches to explaining differences in achieved results. The increasing dynamics of the environment have an impact on the need to search for capabilities to respond to emerging opportunities and to eliminate threats.

Dynamic capabilities constitute theoretical construct useful for understanding the phenomenon of competition, but they differ from operational capabilities primarily due to the emphasis placed on the change management processes. [Cyfert, Krzakiewicz 2017].

The changeability of conditions forces us to create new behaviors and attitudes, which are a response to the transforming reality and provoke the search for sources of building a lasting competitive advantage. The systemic implementation of changes is crucial to an organization, which can improve the process of dynamic capacity development, which is the component of management process in an organization. In the literature on the subject, one of the most important conditions of existence of the organization is the capability to build its competitive advantage [Barney 1991]. Some strategy researchers remain skeptical of the concept of "dynamics capability." However, some view dynamic capability as the key to competitive advantage [Teece et al. 1997].

To ensure terminological consistency, the research process assumes that dynamic capabilities are a set of specific competencies that determine the company's ability to integrate, build and reconfigure internal and external resources/competences that provide the ability to adapt to changing environmental conditions or shape these changes [Teece 2008].

In the research procedure it was assumed that the process of shaping dynamic capabilities consists of five stages:

Stage 1. Searching for opportunities related to analyzing trends and phenomena in the environment, creating new ideas and identifying needs for change.
Stage 2. Learning, related to acquiring knowledge, transfer of knowledge inside the organization, allocation and storage of knowledge within the organization, management of intellectual property, encouraging employees to innovate and do experiments.

Stage 3. Coordination, related to the creation of integrated vision of stakeholders, building loyalty between stakeholders, integration of activities in the supply chain, management of strategic alliances, building employees' engagement, creating consistent decision rules, integration and coordination of business processes.

Stage 4. Configuration and reconfiguration, related to the creation of resources and skills, acquisition of resources and skills, integration of resources and skills, creation of innovation, release of redundant resources and skills, implementation of new technologies.

Stage 5. Adaptation of the organization, related to the transformation of the business model, management of organizational boundaries, ensuring a dynamic strategic management process, organizational improvement, adaptation and implementation of the best management practices, ensuring the flexibility of the organizational structure, management of organizations' identity [Cyfert, Krzakiewicz 2017].

A different perspective than the one described in the mainstream concept of dynamic capabilities [Teece 2008] is presented by K. Eisenhardt and J. Martin [2010], who perceive dynamic possibilities as intra-organizational processes of integration, reconfiguration, and obtaining or releasing resources to ensure compliance with or generation of market changes [Eisenhardt, Martin 2010].

In the research procedure, the concept of A. Osterwald's business model was adopted, which assumes that the business model describes the prerequisites/ways for the means based on which the organization creates value and ensures and profits from this generated value [Osterwalder, Pigneur 2012].

The business model contains elements of operational logic, as the ways of translating the business concept into specific activities and defines the business domain and ways of creating value for the client. It consists of the following elements: business domain, value proposition, distribution

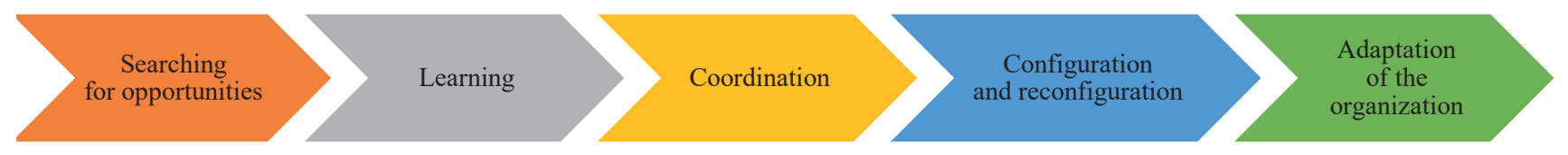

Figure 3. Process of shaping of dynamic capabilities

Source: [Cyfert, Krzakiewicz 2017]. 
channels, customer relations, revenue streams, key resources, key activities, key partners, cost structure [Osterwalder 2004].

The approach to dynamic capabilities, not only high technologies, but also in the context of the economic activity of various entities is discussed in relation to international enterprises [Teece 2014]. Dynamic capabilities in small and medium enterprises are also presented by A. Kuuluvainen [2012]. It is interesting to study other industries, not only related to technology but also for example retail sale of fuels. Similar research on the dynamic capabilities of Polish enterprises was carried out by Polish scientists S. Cyfert, K. Krzakiewicz [2017].

\section{Research methodology and characteristics of the research sample}

The aim of the research is to present a part of the results of the research procedure concerning enterprises on the retail fuel sales market, aimed at developing a paradigm of the concept of dynamic capabilities in strategic management, as well as the identification and analysis of dynamic capabilities and business models of Polish enterprises in the retail fuel market.

The considerations presented in the article refer to surveys in which the questionnaire was addressed to related entities in POPIHN. The modified survey questionnaire by S. Cyfert and K. Krzakiewicz was used as the research tool [2017]. In December 2018 research was carried out among POPIHN member companies. Responses to questionnaires were received from 52 persons of middle and top management from six different organizations. The research was completed in March 2019.

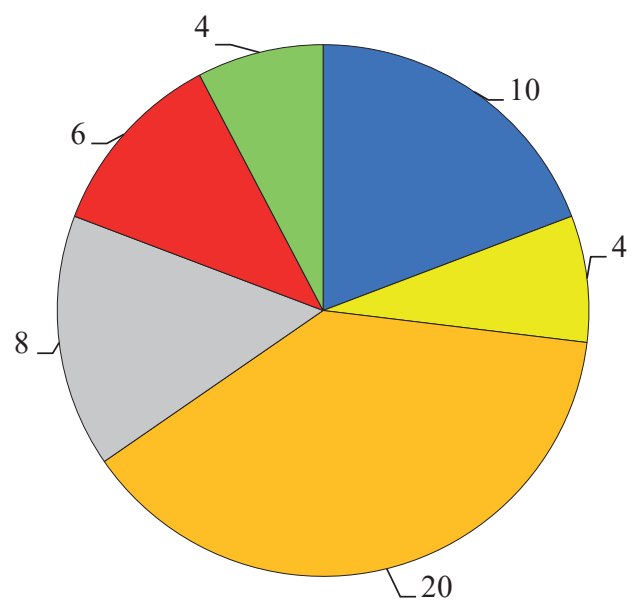

Figure 4. Structure of study participants according to their membership in an organization, $\mathrm{n}=52$

Source: own study based on conducted research.



Figure 5. Structure of the entities surveyed by the criterion of capital employed, $\mathrm{n}=52$

Source: own study based on conducted research.

In the structure of the examined entities, from the point of view of capital employed, enterprises with foreign capital dominated constituting over $75 \%$ of the surveyed population and enterprises with Polish capital accounted for the remaining $25 \%$.

\section{Part of results of the research procedure towards dynamic capabilities in the process of building the effectiveness of the business model}

The research included areas: environment of company, effectiveness, dynamic capabilities and business model.

The respondents answered questions about the level of "turbulence and variability" of the environment on a scale from 1 to 5 , where 1 means a high level of environmental stability, 2 low intensity of changes in the environment, 3 average level of intensity of changes in the environment, 4 a high level of intensity of changes, 5 "stormy" environment.

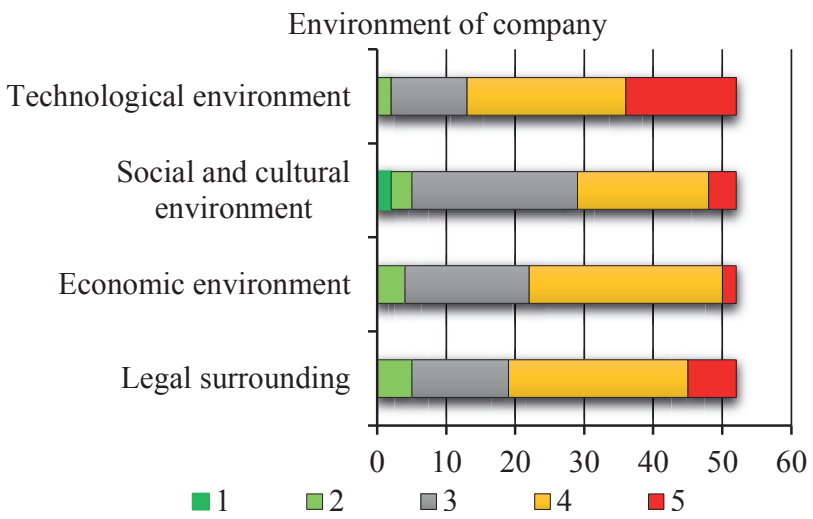

Figure 6. Environment of a company

Source: own study based on the conducted research procedure. 
When asked about the business environment, managers replied that technological environment reached the highest level of intensity of changes with average result of 4.02 and the most stable was social and cultural environment at 3.38. Technological solutions are currently a big challenge for enterprises. Making use of the solutions offered by technologies allows to build the competitive advantage in many business areas.

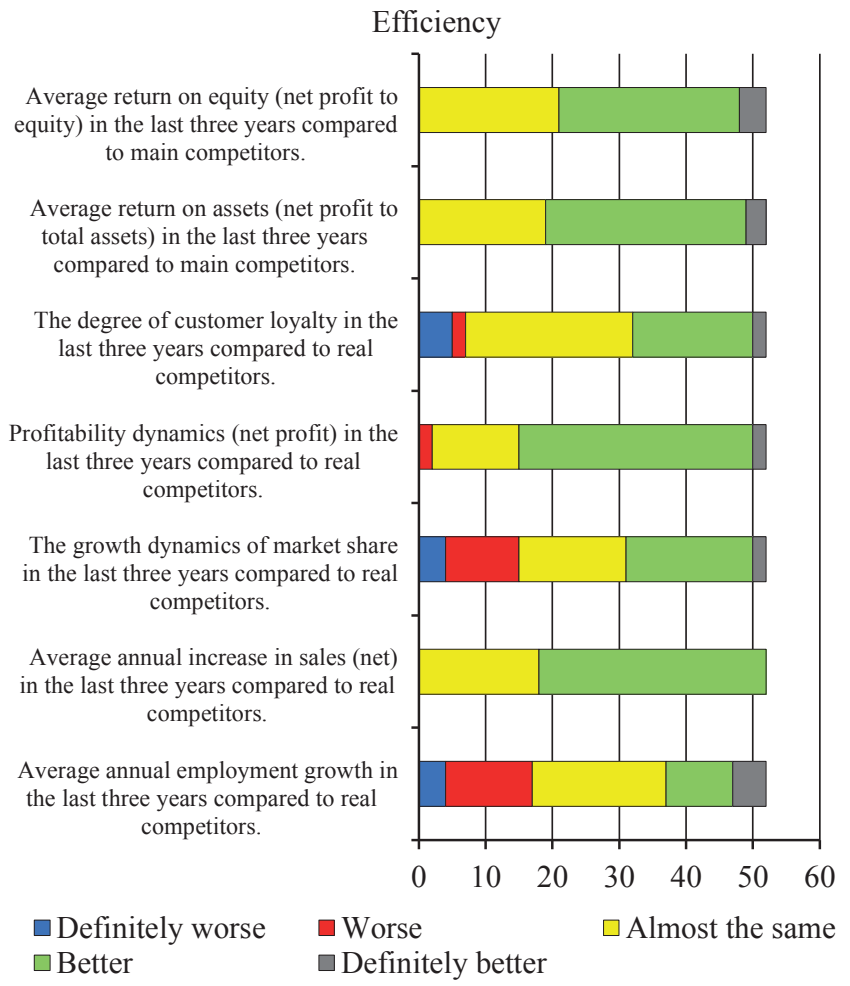

Figure 7. Economic efficiency of a company

Source: own study based on the conducted research procedure.

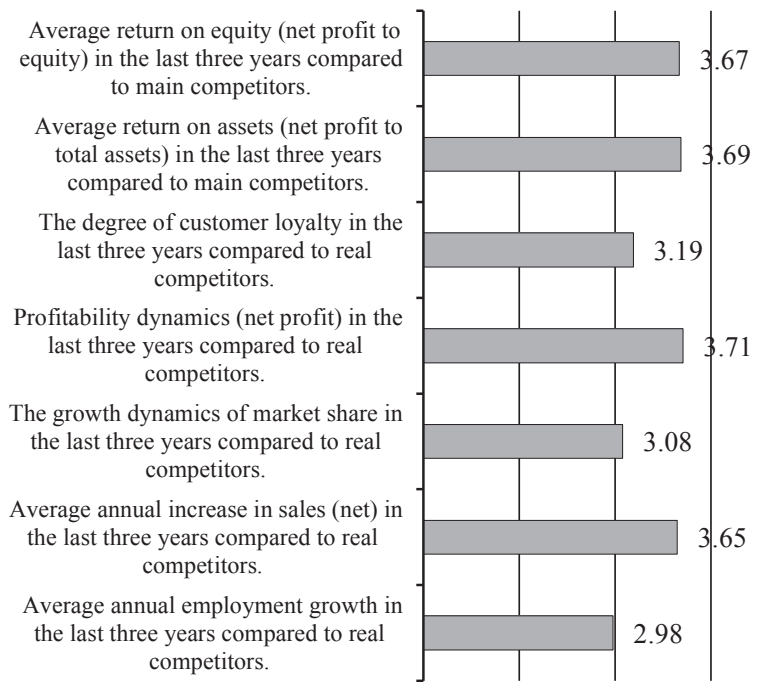

Figure 8. Economic efficiency of a company

Source: own study based on the conducted research procedure.
Respondents evaluated the economic efficiency of a company compared to the effectiveness of other entities in the industry that are actual (their biggest or closest) competitors (on a scale from 1 to 5). The average annual employment growth in the last three years compared to real competitors received the average lowest value of 2.98. The results obtained are analogous to the market situation and the possibility of recruiting employees. Profitability dynamics (net profit) in the last three years compared to real competitors reached 3.71 as the highest average score.

The respondents assessed the importance of individual elements of the business model to ensure the economic efficiency of the company.



Figure 9. Business model

Source: own study based on the conducted research procedure.

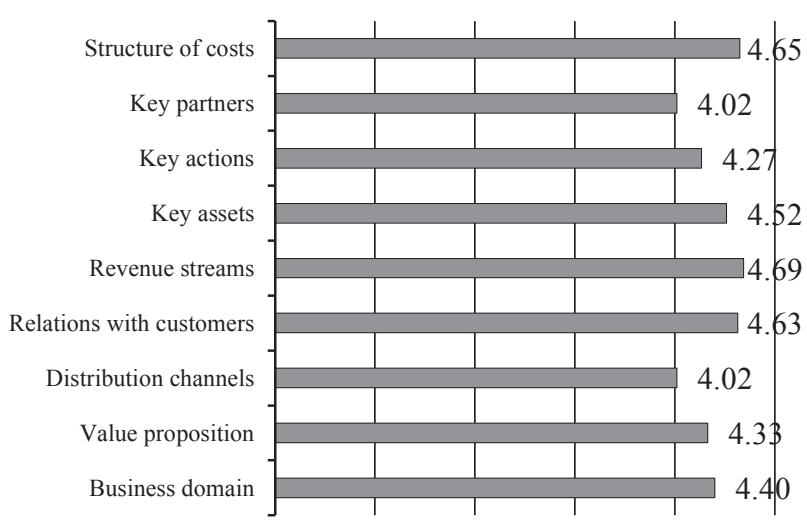

Figure 10. Business model average result

Source: own study based on the conducted research procedure.

The evaluation of individual elements of the business model to ensure economic efficiency relied on respondents choice of revenue streams as the highest average values of 4.69 , followed by the 
structure of costs with the result of 4.65 . The average lowest value was 4.02 and referred to distribution channels and key partners.

\section{Assessment of importance of dynamic capabilities - process approach}

The assessment of the importance of various stages of dynamic capabilities to ensure the economic efficiency of a company is presented in Figure 11. The importance of various stages and intensity of activities is assessed in Figure 12.

\section{Dynamic Capability}



$\begin{array}{ll}\square \text { Irrelevant } & \square \text { Not very important } \square \text { Average meaning } \\ \square \text { Important } & \square \text { Very important }\end{array}$

Figure 11. Assessment of importance of dynamic capabilities Source: own study based on the conducted research procedure.

Dynamic capability - intensity of activities

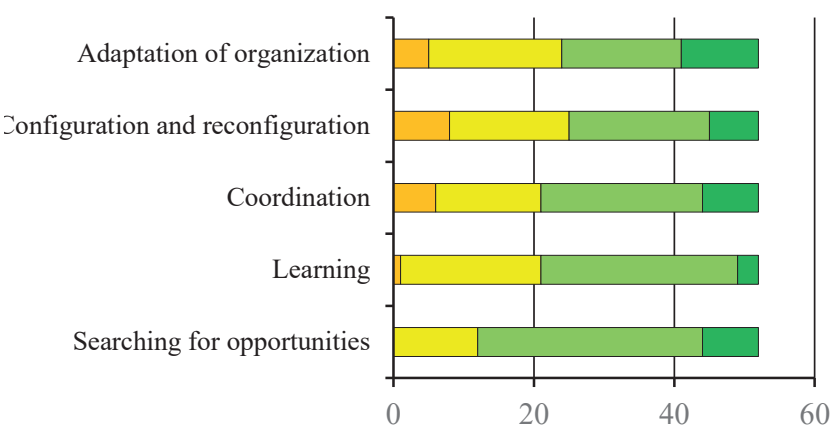

- No occurrence of this factor $\square$ Low level of intensity of activities $\square$ The average level of intensity of activities $\square$ High level of intensity of activities

$\square$ Very high level of intensity of activities

Figure 12. Assessment of intensity of activities

Source: own study based on the conducted research procedure.

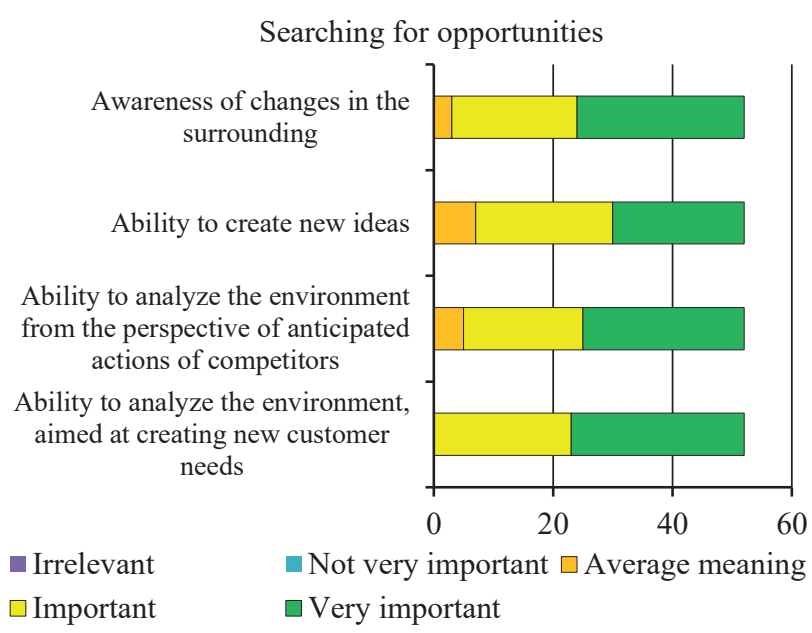

Figure 13. Searching for opportunities

Source: own study based on the conducted research procedure.

\section{Learning}

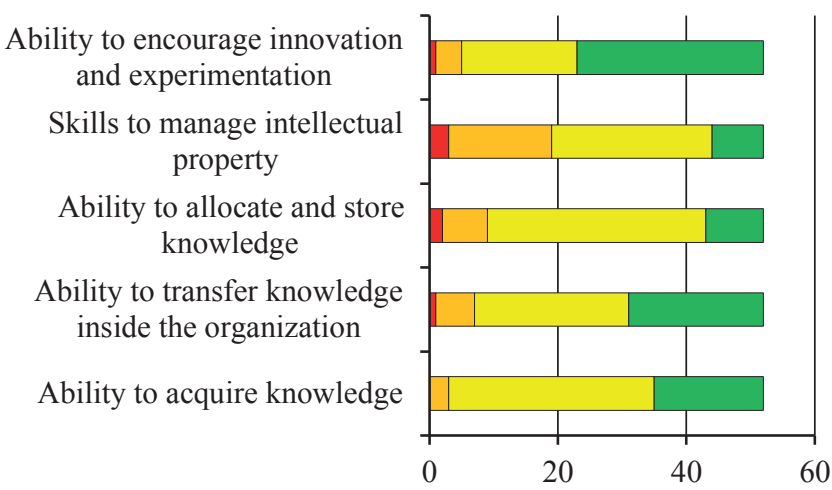

- Irrelevant

$\square$ Important

$\square$ Not very important $\square$ Average meaning $\square$ Very important

\section{Figure 14. Learning}

Source: own study based on the conducted research procedure.

\section{Coordination}

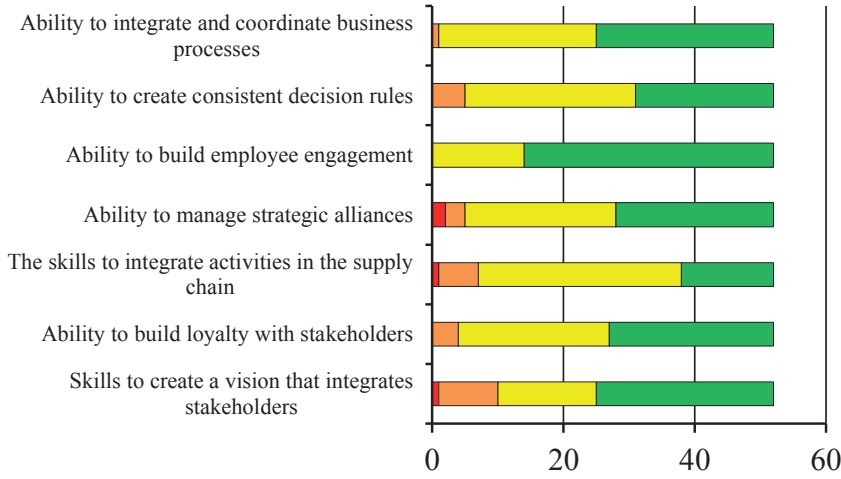

- Irrelevant $\square$ Not very important $\square$ Average meaning $\square$ Important $\square$ Verv important

Figure 15. Coordination

Source: own study based on the conducted research procedure. 


\section{Configuration and reconfiguration}



$\square$ Irrelevant $\quad \square$ Not very important $\square$ Average meaning $\square$ Important $\quad \square$ Very important

Figure 16. Configuration and reconfiguration

Source: own study based on the conducted research procedure.

Adaptation of the organization

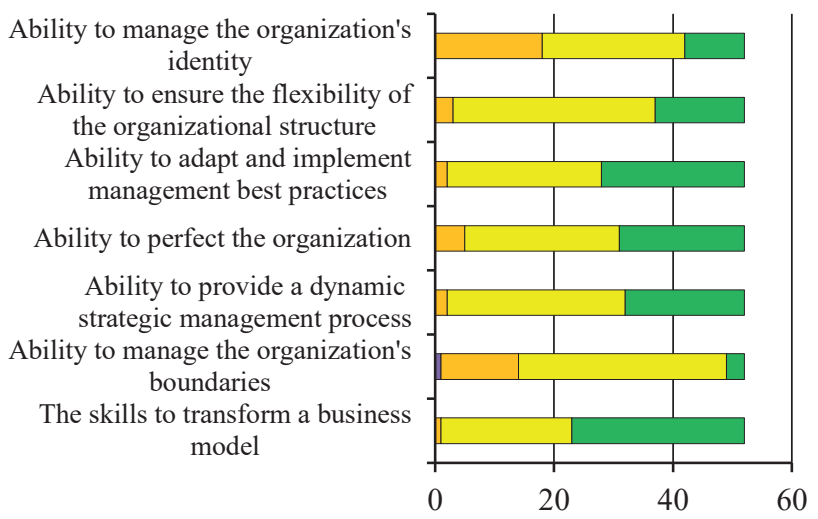

- Irrelevant

$\square$ Important

$\square$ Not very important $\square$ Average meaning $\square$ Very important

Figure 17. Adaptation of the organization

Source: own study based on the conducted research procedure.

\section{Assessment of importance of dynamic capabilities - resources approach}

The importance of resources and skills

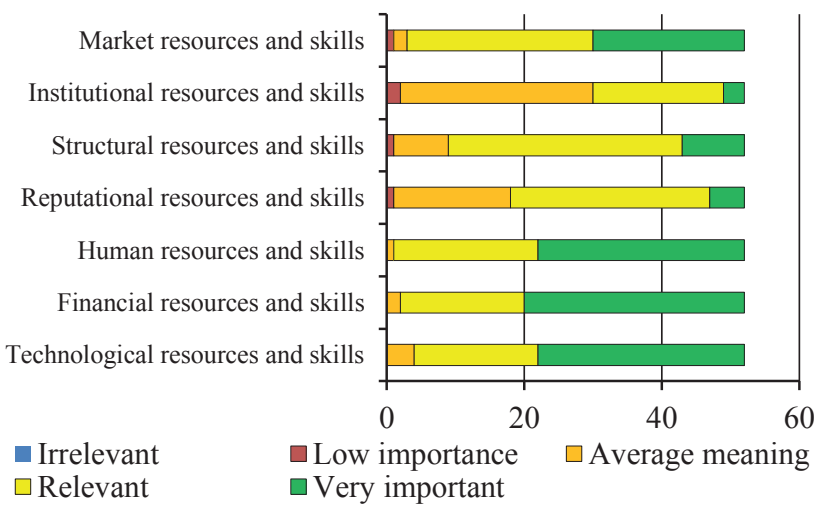

Figure 18. Dynamic capabilities - resources approach

Source: own study based on the conducted research procedure.

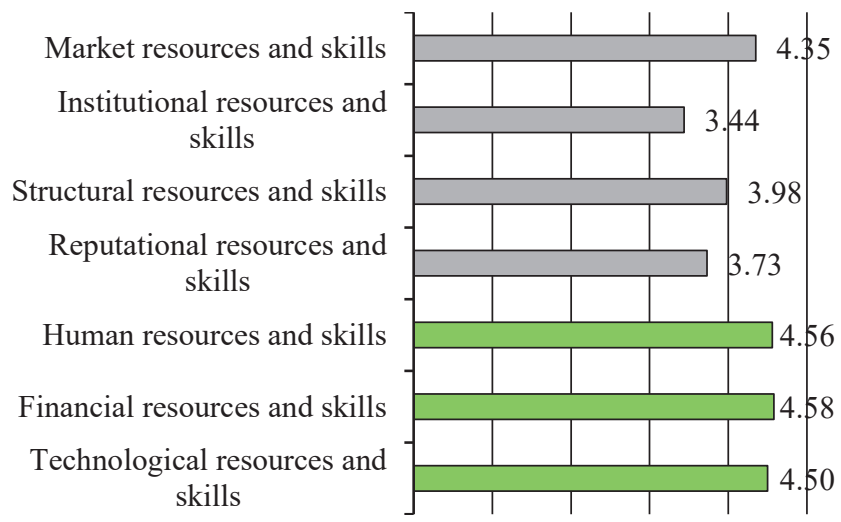

Figure 19. Dynamic capabilities - resources approach

Source: own study based on the conducted research procedure.

The respondents indicated financial resources and skills as the most important capabilities with the score of 4.58 , followed by human resources and skills (4.56) and technological resources and skills (4.50). The average lowest value was 3.44 and referred to institutional resources and skills.

The study was financed by the National Science Centre as part of the project DEC-2013/11/B/HS4/00697.

\section{Conclusions}

The main assumption of the study was to analyze the dynamic capabilities of the organization and business models of the company on the fuel sales market. The key to the research process is the assumption that dynamic capabilities affect the use of business opportunities and optimal resource configuration, which allows organizations to adapt to changes and simultaneously trigger these changes. The assumption adopted is that dynamic capabilities shape the effectiveness of the organization's business models on the retail fuel sales market.

1. The assessment of the environment of company shows a fairly high level of intensity of changes, especially technological changes, rated by respondents at 4.02, which is analogous to dynamic market reality in this aspect.

2. Secondly, the most difficult area that was assessed was the average annual increase in employment over the past three years compared to actual competitors - a score of 2.98. The result confirms the actual picture of the employee market and the difficulty in recruiting new employees.

3. Thirdly, elements of the business model to ensure economic efficiency of enterprises have also been assessed. Revenue streams reached the highest value of 4.69 , followed by a cost structure with a result of 4.65 . The lowest value at 4.02 concerned the distribution channel and key partners. 
4. Subsequently, the research procedure allows us to perceive the high assessment of the significance of individual stages of the process of shaping dynamic capabilities to ensure economic efficiency. According to respondents, the stage of searching for opportunities has the greatest meaning on ensuring economic efficiency (4.60), the weakest meaning has the stage of learning (4.27), all results above average.

The intensity of actions taken at individual stages of shaping dynamic capabilities looks different than the awareness of the importance of these stages. According to respondents, the highest intensity is characterized by actions taken in the search for opportunities (3.92) and the smallest actions in configuration and reconfiguration (3.50).

It seems significant that a gap emerged between the importance and intensity of actions undertaken in particular stages of the process of shaping dynamic capabilities, indicating the creation of added value by activities undertaken in the process.

Only part of the results was presented, ultimately the results of the study are to provide arguments indicating that dynamic capabilities influence the effectiveness of the business model. Business model effectiveness means an organization's ability to create value, capture value and protect. In this way, dynamic capabilities can significantly affect the creation, capture and protection of values.

They can crucially help organizations to achieve above-average results and temporary or permanent competitive advantage.

Dynamic possibilities are a theoretical structure that should be extended with practical tools that will facilitate the work of managers in strategic management of organizations. Therefore, research in this direction should be continued to fill the cognitive gap with new content.

\section{References}

Annual Report by POPIHN 2018, http://www.popihn.pl/raporty2. php.

Act concerning electromobility and alternative fuels, DL 2018, item 317 of 11 January 2018.

Barney J., 1991, Firm resources and sustained competitive advantage, Journal of Management, March, vol. 17, no. 1, pp. 99-120.

Cyfert S., Krzakiewicz K., 2017, Procesy ksztattowania dynamicznych zdolności $w$ polskich przedsiębiorstwach, [in:] K. Krzakiewicz, S. Cyfert (eds.), Strategiczny wymiar dynamicznych zdolności polskich przedsiębiorstw, Wydawnictwo Uniwersytetu Ekonomicznego w Poznaniu, Poznań.

Eisenhardt K.M., Martin J.A., 2010, Dynamic capabilities: What are they?, Strategic Management Journal, no. 21.

Kuuluvainen A., 2012, International growth of a Finnish hightech SME: A dynamic capabilities approach, Research in Economics and Business: Central and Eastern Europe, vol 4., no. 2, pp. 26-40.

Osterwalder A., 2004, The business model ontology a proposition in a design science approach, Universite De Lausanne ecole des Hautes etudes commerciales.

Osterwalder A., Pigneur Y., 2012, Tworzenie modeli biznesowych, Wydawnictwo Helion - One Press, Gliwice.

Teece D.J., Pisano G., Shuen A., 1997, Dynamic Capabilities and Strategic Management, Strategic Management Journal, no. $18(7)$, pp. 509-533.

Teece D.J., 2008, Dynamic Capabilities, [in:] W. Lazonick (ed.), International Encyclopedia of Business and Management, Thomas Learning Publishers, London, pp. 1497-1512.

Teece D.J., 2012, Dynamic capabilities: Routines versus entrepreneurial action, Journal of Management Studies, no. 49, pp. 1395-1401.

Teece D.J., 2014, A dynamic capabilities-based entrepreneurial theory of the multinational enterprise, Journal of International Business Studies, no. 45, pp. 8-37.

\section{DYNAMICZNE ZDOLNOŚCI W PROCESIE BUDOWANIA EFEKTYWNOŚCI MODELI BIZNESU NA RYNKU DETALICZNEJ SPRZEDAŻY PALIW}

Streszczenie: Celem artykułu jest promowanie badań nad koncepcją dynamicznych zdolności. Punktem wyjścia jest prezentacja rynku detalicznej sprzedaży paliw w Polsce i możliwych scenariuszy zmian. Dynamiczny rozwój sektora sprawił, że stacje paliw stały się ważnym elementem infrastruktury publicznej. Jednak ze względu na wysoki poziom konkurencyjności podmioty różnie radzą sobie z przetrwaniem i rozwojem. W takim środowisku konkurencyjnym interesująca wydaje się koncepcja dynamicznych zdolności, która jest jednym z najbardziej obiecujących podejść do wyjaśniania różnic w osiąganych wynikach. Artykuł prezentuje część wyników procedury badawczej przeprowadzonej wśród uczestników rynku detalicznej sprzedaży paliw, ukazuje otoczenie organizacji, model biznesu oraz zdolności dynamiczne zarówno pod względem procesów, jak i zasobów.

Słowa kluczowe: rynek detalicznej sprzedaży paliw, dynamiczne zdolności, efektywność, modele biznesu. 